\title{
Mary and the Other Female Characters in the Protevangelium of James
}

\author{
Petri Luomanen
}

The goal of the present article is to study Jewish female characters in the Protevangelium of James (Prot. Jas.). Despite its name, it is a story about Jesus's mother Mary, starting with her parents Joachim and Anna and closing with events related to Jesus's birth and early childhood. Consequently, throughout the centuries ordinary readers and hearers of the Protevangelium have been mostly interested in the story of Mary. Scholars, for their part, have taken this apocryphal work as a witness of early Mariology. ${ }^{1}$

Because Mary is born to Jewish parents she is by definition the number one Jewish character in the Protevangelium. There are also other Jewish female characters in the story that have not received as much attention as Mary. Furthermore, in the case of Mary, the focus has been on her developing role as the Virgin Mary and the Mother of the God; other traits in her character have been largely ignored. ${ }^{2}$ Thus, the perspective chosen for this article turns

1 Because the close colleague whom the present Festschrift honors has devoted a significant part of his scholarly career to studying Mary in non-canonical texts, it seemed appropriate to write an essay on an apocryphal gospel where Mary is the protagonist. For this project, it is unfortunate that one of the honoree's articles has clipped the wings of a theory that tries to show how the two Marys, the Magdalene and the Mother of Jesus, were fused together in gnostisizing sources. See Antti Marjanen, "The Mother of Jesus or the Magdalene? The Identity of Mary in the So-Called Gnostic Christian Texts," in Which Mary? The Marys of Early Christian Tradition, ed. F. Stanley Jones (Leiden: Brill, 2003), 31-41; cf. Stephen J. Shoemaker, "Rethinking the 'Gnostic Mary': Mary of Nazareth and Mary of Magdala in Early Christian Tradition," JEcs 9 (2001): 555-595; Stephen J. Shoemaker, "A Case of Mistaken Identity? Naming the Gnostic Mary," in Which Mary?, 5-30. In the case of the Protevangelium of James it is clear that the protagonist is Mary the Mother of Jesus. However, a closer look at the characterization in Protevangelium reveals features that may, after all, show some resemblance between the two Marys.

2 Other perspectives have entered the study of Protevangelium slowly. Lily Vuong's monograph is an example of literary analysis of Mary's character in the light of Jewish purity laws and practices. Lily C. Vuong, Gender and Purity in the Protevangelium of James, WUNT 2/358 (Tübingen: Mohr Siebeck, 2013). Earlier studies applying a literary or narrative approach

(C) PETRI LUOMANEN, 2017 | DOI: 10.1163/9789004344938_008

This is an open access chapter distributed under the terms of the CC BY-NC-NP.4.0 license nen $_{\text {- }} 9789004344938$ 
attention to features that have traditionally been considered marginal in the narrative. From the viewpoint of narrative analysis, minor characters, and even characters that exist only to provide a setting for the story, are also important for conveying the message, ${ }^{3}$ although their effect on readers is generally more subliminal than that of the protagonist or the plot of the narrative. Before the actual analysis an introduction to the story and the historical background of the Protevangelium is in order. Because I approach the texts from the viewpoint of narrative analysis I also include a short methodological discussion with definitions of some key concepts to be used.

\section{The Story, Dating, and the Historical Context of the Protevangelium of James}

The Protevangelium of James was most likely composed in the second half of the second century. It was written in Greek, either in Syria or Egypt. ${ }^{4}$ The obvious reason for its writing is to praise Mary but it is also generally assumed, for good reason, that the text was prepared in order to refute Jewish accusations about Mary's character as exemplified, for instance, in Origen's Contra Celsum. ${ }^{5}$ The main character in the text is Mary and Greek manuscripts have titled it accordingly, for instance, as The Birth of Mary: Apocalypse of James (in the Papyrus Bodmer $\mathrm{v}$ from the late third or early fourth century) or An Account of

to the Protevangelium, along with other sources, include Beverly Roberts Gaventa, Mary: Glimpses of the Mother of Jesus, Studies on Personalities of the New Testament (Columbia: University of South Carolina Press, 1995), and Mary F. Foskett, A Virgin Conceived: Mary and Classical Representations of Virginity (Bloomington: Indiana University Press, 2002). In all these literary/narrative approaches the focus is on the characterization of Mary. Other female characters receive little attention.

3 Cf. Gaventa, Mary, 23; James L. Resseguie, Narrative Criticism of the New Testament: An Introduction (Grand Rapids: Baker Academic, 2005), 123-124.

4 Silvia Pellegrini, "Das Protevangelium des Jakobus," in Evangelien und Vervandtes, vol. I/2 of Antike christliche Apokryphen in deutscher Übersetzung, ed. Christoph Markschies and Jens Schröter (Tübingen: Mohr Siebeck, 2012), 903-929, esp. 907-909.

5 Thus P. Van Stempvoort, "The Protevangelium Jacobi: The Sources of its Theme and Style and Their Bearing on its Date," in SE III, ed. F.L. Cross, TUGAL 88 (Berlin: Akademie Verlag, 1964), 410-426, esp. 413-415; Roland F. Hock, The Infancy Gospels of James and Thomas: With Introduction, Notes, and Original Text Featuring the New Scholars Version Translation. The Scholars Bible 2 (Santa Rosa: Polebridge, 1995), 11-12, 15-20. Cf. Origen, Cels. 1.28, 32, 69 . 
the Birth of Theotokos (Georgian translation). ${ }^{6}$ The present article is based on Roland F. Hock's critical edition of the Greek text. ${ }^{7}$

The text received its present title, the Protevangelium of James, in the midsixteenth century when it was re-introduced in the West by Guillaume Postel. The title is based on the concluding note of the "author" who obviously identifies himself as James the brother of Jesus (Prot. Jas. 25.1-2). In the narrative world of Protevangelium, James is Joseph's son from his previous marriage (Prot. Jas. 9.2). He follows Joseph and Mary to Bethlehem where they go to be enrolled for the census (Prot. Jas. 17.1). He also keeps guard, together with his brother(s), outside the cave where Jesus was to be born, when Joseph goes out to look for a midwife around Bethlehem (Prot. Jas. 18.1).

Chapters 1-7. Joachim and Anna have not received offspring. They feel ashamed and are even rebuked by their fellow Israelites. They mourn and lament their lot and pray to be blessed like Abraham and Sarah who were given Isaac in their late days. Their prayers are heard and Anna becomes pregnant. The manuscripts differ over whether Joachim hears from the angel that Anna has become pregnant or will become pregnant. ${ }^{8}$ If the perfect tense $(\varepsilon i \lambda \eta \varphi \varepsilon v)$ is original, then even Mary's conception might have been miraculous, although clearly not "virginal" because the narrative presupposes that Joachim and Anna have tried to get offspring. ${ }^{9}$ After Mary is born, Anna devotes herself to protecting Mary's purity in her bedroom that is turned into a sanctuary, assisted by "the Hebrews' undefiled daughters." When Mary turns three she is eventually handed over to the Lord in the Temple in order to fulfill the promise Anna made when an angel announced that her prayers had been heard (Prot.Jas. 4.1). When

6 Émile De Strycker and Hans Quecke, La forme la plus ancienne du Protévangile de Jacques: Recherches sur le papyrus Bodmer 5 avec une édition critique du texte grec et une traduction annotée par Emile de Strycker, S.J., En appendice les Versions arméniennes traduites en latin par Hans Quecke, s.J. Subsidia hagiographica 33 (Bruxelles: Société des Bollandistes, 1961), 211-212.

7 Hock's reconstruction of the Greek (Hock, The Infancy Gospels) differs slightly from de Strycker's edition (de Strycker, La forme). Hock also applies his own division of the text into verses, which I have not followed.

8 For the discussion concerning this textual problem, see Hock, The Infancy Gospels, 38-39.

9 Hock argues for a miraculous conception. Consequently, he also chooses to read "nine months" as the duration of Anna's pregnancy in Protevangelium 5.2 where manuscripts provide several options: six, seven, eight, and nine months are all attested. See Hock, The Infancy Gospels, 39 n. 4:4, and 41. Pellegrini ("Das Protevangelium," 913 n. 54) chooses a shorter time and argues that the logic of the narrative allows Joachim to have given his seed before he left for the wilderness. 
Mary is escorted to the temple she dances "and the whole house of Israel loved her." After this, Joachim and Anna do not appear in the narrative again.

Chapters 8-16. As Mary is approaching womanhood she cannot stay in the Temple any longer because the text suggests that her menstruation would pollute it. ${ }^{10}$ Zacharias, the high priest, is instructed by an angel to call together the widowers of the people in order to find her a husband. Joseph is among the widowers and is selected by a miraculous sign: a dove coming from his staff. Joseph objects by referring to his old age and the fact that he already has sons. Scared by some examples of what has happened to people who have not feared God, Joseph consents to give Mary "care and protection." Joseph's old age and reluctance are stated in order to make it clear that he has no sexual desires towards Mary. That no sexual relations take place between them is also emphasized by relating that immediately after receiving Mary from the Temple Joseph goes out to build houses, leaving Mary home.

While Joseph is building houses Mary is kept busy at home: she is elected as one of the pure maidens who are to spin threads for the new veil of the Temple. She is also visited by a heavenly messenger at a well and she learns that she will become pregnant by the word of the Lord and give birth, but not the way women usually do. At this point, the narrative starts to pick up elements from the synoptic infancy stories: Mary is told that she shall name the child Jesus (cf. Matt 1:21), and she visits her relative Elizabeth (cf. Luke 1:39-45, 56).

Mary is six months pregnant when Joseph returns home from his building projects. He becomes terrified, compares his situation to that of Adam when Eve was deceived by the snake, and starts questioning Mary who claims to be innocent. Joseph is convinced when an angel appears to him in a dream. However, Joseph and Mary still have to convince the high priest. This happens through a drink test which both Joseph and Mary pass unharmed. The test is apparently something similar to what is described in Numbers 5:11-31, although there it is applied only to women suspected of adultery.

Chapters 17-20. In these chapters the Protevangelium links up more closely with the canonical gospels. Augustus's census motivates Joseph and Mary's journey to Bethlehem. In contrast to Matthew's and Luke's narratives, they are followed by Joseph's sons from his previous marriage. When Joseph goes to look for a "Hebrew midwife" he leaves them to keep guard outside the cave where Mary is waiting. The midwife arrives in time to testify to a miraculous birth with a dark cloud first overshadowing the cave and then giving way to a bright light

10 Although menstruation is not explicitly mentioned, the discourse clearly presupposes it, as aptly argued by Vuong, Gender and Purity, 120-125. 
that reveals the newborn. She is convinced. That is not the case with Salome who hears about the birth from the midwife. Salome wants to examine Mary but when she inserts her finger into Mary, her hand becomes consumed by flames. She is healed, however, when she picks up Jesus and acknowledges him as the one who has been born to be the king of Israel.

Chapters 21-25 tell about the astrologers' visit and Herod's murder of infants (not just boys in this narrative) of two years old and younger. Mary manages to save Jesus by hiding him in a manger (Prot. Jas. 22.2). This short note is also the last reference to Jesus in the narrative that, in contrast to synoptic infancy narratives, gives more space to the history of John the Baptist's parents. Elizabeth and John are saved when a mountain splits and lets them in. Zechariah, the father, however, is killed by Herod's servants because he refuses to disclose the whereabouts of his son (chapter 23). Chapter 24 describes in detail how other priests learn about Zechariah's murder. When "tribes of the people" hear about the murder they mourn for three days and nights. ${ }^{11}$ The Protevangelium even appears to refer to Zechariah as the high priest (Prot. Jas. 8.3, 10.2, 23.1-3). The Protevangelium closes with the author's self-description as described above.

\section{The Narrative Approach and the Key Concepts}

Although the focus of the present article is on characterization, it goes without saying that attention must also be paid to other elements of the narrative. Characterization and plot are tied closely together since characters of narrative, if not providing mere background (see below), are also active agents that contribute to causality and sequence in the narrative. ${ }^{12}$ The way that characters act reveals some traits of their personality. ${ }^{13}$ Narrator's and other characters'

11 Because Zechariah is murdered when he is serving at the altar, the story may have been inspired by Matt 23:35 (thus, Hock, The Infancy Gospels, 75). However, in Matthew it is the Pharisees and Scribes who are blamed for the murder of Zechariah the son of Barachiah. In the Protevangelium it is Herod and his servants who are responsible for the murder while the priests and people are described in a good light.

12 For the relationship between characters and plot, see Seymor Chatman, Story and Discourse: Narrative Structure in Fiction and Film (Ithaca: Cornell University Press, 1978), 108116.

13 I follow here, slightly modifying, Chatman (Story and Discourse, 120-123) by understanding traits as a) more general than simple habits, b) empirically verifiable, c) partly overlapping, not totally independent of all other traits so that an understandable identity of a personality appears, and d) possibly contradictory with some other traits. 
comments and descriptions also add to the traits of a character's personality, and so does also the character's own speech. The environment and the social context where a character appears also makes it possible for the audience to make inferences about the personal traits of the character. ${ }^{14}$ In addition to traits the personality of a character also requires some degree of uniqueness and stability that makes it possible to distinguish the person from others. ${ }^{15}$

E.M. Forster's distinction between round and flat characters is widely used in narrative analysis. Flat characters lack complexity and may exhibit only one trait. "In their purest form they are constructed round a single idea or quality: when there is more than one factor in them, we get the beginning of the curve towards the round." Round characters exhibit several traits that can even be contradictory. They are "capable of surprising in a convincing way."16 Characters without any, even flat, personal identity can also be called walk-ons. They are nameless and can be taken as the setting or background of the narrative. ${ }^{17}$ Crowds and Roman soldiers can be regarded as collective walk-ons in the gospel narratives. ${ }^{18}$ This does not, however, mean that they are necessarily insignificant for the development of the narrative. For instance, walk-ons can function as a foil that adds depth to other characters' personality by providing contrast to their traits. The definition of foil is functional; foil characters can be round or flat. What makes them foils is their contrastive relation to other characters. Stock characters are characters typical of certain literary genres. An example is cruel stepmothers in fairy tales.

Collectives and groups often exhibit stability and traits which makes it possible to distinguish them from other groups. This raises the question about their relation to individual characters. Because the human mind is able to perceive and process groups mainly though abstract conceptualizations, by stereotyping and focusing on some distinctive features, ${ }^{19}$ it is clear that as far

14 Cf. Resseguie, Narrative Criticism, 121-122.

15 Chatman's starting point in his discussion of character is the definition in the Dictionary of Philosophy, edited by Dagobert Runes, 1975 (Chatman, Story and Discourse, 120 n. 28). Chatman summarizes his considerations as follows: "I argue-unoriginally but firmlyfor a conception of character as a paradigm of traits; 'trait' in the sense of 'relatively stable or abiding personal quality.'" Chatman, Story and Discourse, 126.

16 E.M. Forster, Aspects of the Novel (London: Edvard Arnold Publishers, 1927; repr. 1958), 6575, esp. 65, 75; Resseguie, Narrative Criticism, 123-124.

17 Chatman, Story and Discourse, 139-141.

18 Resseguie, Narrative Criticism, 125.

19 Social psychology, especially the social identity approach that was developed by Henry Tajfel and his colleagues, has developed ample concepts, like stereotypes, exemplars and 
as groups function like characters they appear at the flat end of the round-flat continuum. ${ }^{20}$

The relative importance of the characters for the overall narrative and its development also needs to be noted. Protagonist is the term used for the main character of the story. Originally the term was used for the leading, first actor in Greek plays, $\pi \rho \omega \tau \alpha \gamma \omega \nu i \sigma \tau \eta \dot{s}$, which implies that the protagonist was the character whose actions were essential for the development of events in the play. Especially when applied in literary studies, the possibility emerges that the character who is most closely followed in the narrative does not have much effect on the causal chain of events. This seems to be the case in the Protevangelium of James where Mary's actions are not essential for the plot, as previous narrative analyses have revealed (more on this below) ${ }^{21}$ Narratives can also have several protagonists, who may dominate different parts of the narrative. Relative importance can also be generally described by referring to major and minor characters. Characters can also develop in the course of the narrative. If such is the case the character can be termed as dynamic. On the other hand, static characters remain essentially the same throughout the narrative. ${ }^{22}$

The following narrative analysis presumes the standard distinction between story (content) and discourse (expression). ${ }^{23} \mathrm{I}$ am also using the terminology from the so-called Booth and Chatman communication model, which makes distinctions, for instance, between real and implied authors as well as real

prototypes, for analyzing group categorizations. These concepts make it possible to combine literary and narrative analyses with social-scientific perspectives. For the use of the social identity approach in biblical studies, see J. Brian Tucker and Coleman A. Baker, eds., $T \&$ C Clark Handbook to Social Identity in the New Testament (London: Bloomsbury, 2014). For the cognitive background of the approach and further discussion of its concepts, see Petri Luomanen, "The Sociology of Knowledge, the Social Identity Approach and the Cognitive Study of Religion," in Explaining Christian Origins and Early Judaism: Contributions from Cognitive and Social Science, ed. Petri Luomanen, Ilkka Pyysiäinen, and Risto Uro, BibInt 89 (Leiden: Brill, 2007), 199-229, and Petri Luomanen, "Matthew's Corpus Mixtum in the Perspective of the Social Identity Approach," in Voces Clamantium in Deserto, ed. Sven-Olav Back and Matti Kankaanniemi, Studier i exegetik och judaistik utgivna av Teologiska fakulteten vid Åbo Akademi 11 (Åbo: Åbo Akademi, 2012), 199-215.

20 Cf. Resseguie, Narrative Criticism, 123, 125.

21 Foskett, A Virgin Conceived, 16o-161; Vuong, Gender and Purity, 242; Gaventa (Mary, 120) also regards Mary's character as flat.

22 Resseguie, Narrative Criticism, 123-126.

23 I am applying here the standard distinction in narrative analysis between story (content) and discourse (expression) as defined by Chatman, Story and Discourse, 22-26. 
and implied audiences. ${ }^{24}$ Although I am analyzing characterization, I am also setting the discussion in the original historical context of the Protevangelium. ${ }^{25}$ Therefore when I refer, for instance, to the author, I usually have the real author in mind unless stated otherwise.

\section{Jewish Female Characters in the Protevangelium of James}

\section{Mary}

Virginity is obviously one of the most central traits in Mary's character and it has been important in subsequent Christian reception of the Protevangelium. ${ }^{26}$ Nevertheless, as Vuong convincingly shows, the purity of Mary is the overarching theme of the narrative, and virginity is only one aspect of her purity. ${ }^{27} \mathrm{Her}$ mother Anna "did not permit anything profane or unclean to pass the child's lips" (Prot.Jas. 6.1). ${ }^{28}$ This is in line with the promise Anna gave when she was informed that her prayers had been heard and she would conceive and give birth. Whether the baby would be a boy or a girl Anna "will offer it as a gift to the Lord" (Prot. Jas. 4.1). Naturally, the gifts offered to the Lord have to be kept pure.

The safeguarding of Mary's purity dominates the narrative and explains some of its features that are usually regarded problematic from the historical point of view. For instance, several scholars have taken the fact that at the age of three Mary is moved to the temple as one indication of the author's ignorance of Jewish temple service. ${ }^{29}$ From the viewpoint of the narrative the moving is

24 See, for instance, Chatman, Story and Discourse, 151.

25 In this regard, I agree with Petri Merenlahti and Raimo Hakola who advocate the useful interaction of narrative analysis and historical inquiry. See Petri Merenlahti and Raimo Hakola, "Reconceiving Narrative Criticism," in Characterization in the Gospel: Reconceiving Narrative Criticism, ed. David Rhoads and Kari Syreeni. JSNTSup 184 (Sheffield: Sheffield Academic, 1999), 13-48.

26 J.K. Elliott, "Christian Apocrypha and the Developing Role of Mary," in The Oxford Handbook of Early Christian Apocrypha, ed. Andrew Gregory and Christopher Tuckett (Oxford: Oxford University Press, 2015), 269-288, esp. 270-272; Charlotte Touati and Claire Clivaz, "Apocryphal Texts About Other Characters in the Canonical Gospels," in The Oxford Handbook of Early Christian Apocrypha, 48-51.

27 For a summary, see Vuong, Gender and Purity, 240-244.

28 Translations of Protevangelium of James in this article follow Hock's edition (Hock, The Infancy Gospels), with slight modifications. However, I have not adopted Hock's verse numbering.

29 Oscar Cullmann, "Kindheitsevangelien," in Neutestamentliche Apokryphen in deutscher 
a most natural expression of Mary's purity: she is kept pure from the day of her birth and given as a pure gift to the Lord as promised. She dwells undefiled in the temple just as her womb will later provide a pure dwelling for the Son of God. In this way Mary's purity is made comparable to the purity of the temple. ${ }^{30}$

As noted above, earlier narrative analyses of Mary have paid attention to some peculiar features in her characterization. Although she is the main character in the narrative she is more often an object than the subject of action. Consequently, her character appears as relatively flat. ${ }^{31}$ Sparse description of mental and physical traits is typical of biblical as well as ancient Mesopotamian and Syro-Palestinian literature. Therefore, Robert Alter thinks that biblical authors developed other literary means - such as plot development, contrast and comparison - through which they were able to add depth and complexity to their characters. In Vuong's view, Mary's own voice in the Protevangelium of James serves this purpose.

Mary speaks only in five instances in the entire narrative. Voung finds this a deliberate contrastive structure that the author uses in order to heighten the significance of Mary's message when she speaks. The speeches also add roundness to Mary's character. In Vuong's view, she becomes an example of

Übersetzung: 1, Evangelien, ed. Edgar Hennecke and Wilhelm Schneemelcher (Tübingen: Mohr Siebeck, 1987), 330-372, esp. 337; J.K. Elliott, The Apocryphal New Testament: A Collection of Apocryphal Christian Literature in an English Translation (Oxford: Oxford University Press, 1993); Hock, The Infancy Gospels, 10. Although Mary's living in the temple does not cohere with Second Temple practices, the story also includes elements that may indicate the author's knowledge of some later Jewish traditions. Mary is transferred to the temple at the age when her virginity is becoming more vulnerable. According to Mishnaic tradition, before the age of three the hymen of girls would regenerate spontaneously. See Timothy J. Horner, "Jewish Aspects of the Protevangelium of James," JEcs 12 (2004): 313335, esp. 321-324; cf. m. Nid. 5:4; m. Ketub. 1:2-3. There is also a tradition about temple virgins who were responsible for weaving the temple curtains. See Megan Nutzman, "Mary in the Protevangelium of James: A Jewish Woman in the Temple?" GRBS 53 (2013): 551578, esp. 563-570; cf. m. Šeqal. 8:5; t. Šeqal. 2:6; 2 Bar 10:18-19. All this indicates that the author of Protevangelium did not just consult the Septuagint for Jewish practices but was also aware of some contemporary Jewish traditions and used them creatively for literary purposes. For a more detailed discussion of the relation of Protevangelium of James to Judaism, see Petri Luomanen, "Judaism and Anti-Judaism in Early Christian Apocrypha," in The Oxford Handbook of Early Christian Apocrypha, 319-342, esp. 319328 .

$30 \quad$ Vuong, Gender and Purity, 88-103.

31 See above, n. 21. See Robert Alter, The Art of Biblical Narrative (London: Georg Allen \& Unwin, 1981), 114-115; Vuong, Gender and Purity, 242 n. 6. 
women "who maintain their innocence and purity even when questioned by the highest male authorities." ${ }^{22}$ Surely Mary's speeches add something to her character, but it is questionable how much depth there actually is. The first scene where Mary speaks is when she is addressed by a heavenly messenger, later identified as Gabriel:

But as she listened, Mary was doubtful and said, "If I actually conceive by the Lord, the living God, will I also give birth the way women usually do?" ... And Mary said, "Here I am, the Lord's slave before him. I pray that all you have told me comes true."

Prot. Jas 11.2-3, trans. HOCK 1995, slightly modified

The second scene where Mary voices her thoughts is her visit to her relative Elizabeth, John the Baptist's mother. After Elizabeth has hailed Mary the discourse continues:

But Mary forgot the mysteries which the heavenly messenger Gabriel had spoken, and she looked up to the sky and said, "Who am I, Lord, that every generation on earth will congratulate me?"

Prot. Jas. 12:2

In the third scene, Joseph questions Mary, who replies:

But she began to cry bitter tears: "I am innocent. I have not had sex with any man."

And Joseph said to her, "Then where did the child you are carrying in your womb come from?" And she replied, "As the Lord my God lives, I do not know where it came from."

Prot. Jas. $13.2-3$

Later on, Mary also replies to the high priest who is questioning her (Prot. Jas. 15.3):

But she began to cry bitter tears: "As the Lord God lives, I stand innocent before him. Believe me, I have not had sex with any man."

Prot. Jas. $15 \cdot 3$

32 Vuong, Gender and Purity, 242. To be exact, Mary speaks eight times but this happens in five (or six, if one counts the last one as two) different scenes. Vuong refers to Mary speaking only five times. 
Finally, Mary speaks when Joseph wants to know the reason for her rapidly changing moods.

And she replied, "Joseph, it is because I imagine two peoples in front of me, one weeping and mourning and the other celebrating and jumping for joy." Halfway through the trip Mary said to him, "Joseph, help me down from the donkey — the child inside me is about to be born."

Prot. Jas. 17.2-3

After this Mary does not say anything further in the narrative of the Protevangelium. The scenes are related to three themes. The first and the second deal with the annunciation in dialogues with Gabriel and Elizabeth. In the third and the fourth Mary is questioned about her pregnancy. The fifth presents prophetic words about the reception of the child that is about to be born.

Do these speeches add depth to Mary's characterization? It is true that in the third and the fourth scene Mary defends herself in the face of Joseph's and the high priest's accusations. The content of her speech hardly surprises the audience; she simply states the plain fact that the audience has known throughout the narrative. If one of the characteristics of a round character is an ability to surprise, that does not happen here, at least as far as the content of Mary's speech is concerned. Still it is remarkable that in the two cases where Mary defends her virginity she leaves her otherwise submissive role and stands up for her case. Does this make Mary a role model for women who wish to maintain their integrity in front of male authorities-in this case her husband and the high priest? Perhaps so, if a woman should happen to be wrongly accused of adultery. Otherwise I am doubtful because Mary mostly has a submissive role in the narrative.

Despite her quick development-she walks at the age of six months and at the age of three years she walks up the temple stairs and dances (Prot. Jas. 6.1, 7.2-3) - she does not say a word when the priests are making plans about her future at the age of twelve (Prot. Jas. 8.2-3). She remains silent even when Joseph directly addresses her telling her that he has received her from the temple - and will immediately leave her alone at home in order to go away to build houses (Prot. Jas. 9.3). At this point, even the narrator remains silent about Mary's reaction. When the virgins are commissioned to weave the temple curtains, Mary silently receives the threads that befell her (Prot. Jas. 10). When Joseph and Mary are subjected to the adultery test, Mary remains silent, and after the test only Joseph's reaction is described (Prot. Jas. 16). When Joseph ponders how to enroll Mary for Augustus's census and leaves for Bethlehem setting her on his donkey she remains silent (Prot. Jas. 17.1-2). She does not reply 
when Joseph directly asks her where to take her in order to secure the privacy of her delivery (Prot.Jas. 17.3). Perhaps the most striking and most telling about the submissive traits in Mary's character is the scene where the second midwife Salome comes to the cave and orders Mary to position herself for examination. Mary submits without complaints and Salome inserts her finger into Mary (Prot. Jas. 20.1).

It is perhaps not surprising that the overall narrative coheres with patriarchal structures and male dominance. What is striking is that Mary does not engage in ordinary discussions with her spouse/guardian as, for instance, her mother Anna does. In this regard Mary's character clearly differs from other more active female characters in the Protevangelium, as becomes clear below. Against this background it is hard to take Mary's character as a role model of an individual who speaks out with her own voice displaying courage and strength. ${ }^{33}$ On the contrary, it seems that when Mary is allowed to speak she voices the theological ideas of the author who most probably was male. ${ }^{34}$

Mary's first dialogue with Gabriel makes it clear for the audience that she will not just miraculously become pregnant but will also deliver the baby unlike any other woman. In contrast to Luke's version of the annunciation Mary does not wonder at all how she can become pregnant, but wonders if she will also give birth the usual way (cf. Luke 1:34). The dialogue clearly anticipates the scene with the midwives where the author does not hesitate to submit Mary's private parts that have remained thus far untouched and pure to Salome's intrusion. The theological point becomes clear: Mary was proven virgin even after the delivery. Because there was no bleeding, Mary is also able to give breast to the child immediately after giving birth (Prot. Jas. 19.2; cf. 5.2 where Anna first waits for the required time and cleanses herself). ${ }^{35}$

If the Protevangelium was originally composed in response to Jewish accusations concerning Mary's reputation it is no wonder that the author gives voice to Mary at the points where her virginity is questioned. Mary's prophetic words about the two nations continue the theme. Her birth pangs do not only anticipate the birth of the Lord, but metaphorically also the birth of a new group of believers who receive him and rejoice. ${ }^{36}$

\footnotetext{
33 Cf. Vuong, Gender and Purity, 242.

34 At least the implied author of the Protevangelium, James, is male.

35 Vuong, Gender and Purity, 89-9o.

36 It has been suggested that the twofold reception could refer to the positive response among Christians and negative among Jews, as the same scene does explicitly in the Gospel of Pseudo-Matthew (13.1), but this kind of distinction does not hold with the overall positive characterization of the "people of Israel" in the narrative of Protevangelium. The dividing line is not drawn between "Christians" and the "people of Israel" but believers
} 
To be sure, Mary's character receives some roundness through the narrator, who occasionally attributes emotions to her. In Mary's childhood, dancing may imply her being happy (Prot. Jas. 7.3). After that we do not learn about her emotions until the annunciation where the narrator describes her as being

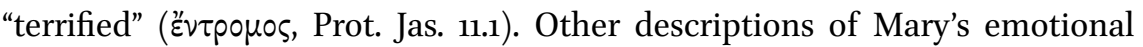
and cognitive reactions include being doubtful when Gabriel addresses her ( $\delta\llcorner\varepsilon x p i \theta \eta$, Prot. Jas. 11.2), rejoicing as she hears the high priest's prophetic words $(\chi \alpha \rho \dot{\alpha} \nu \delta \dot{\varepsilon} \lambda \alpha \beta \beta \hat{\sigma} \sigma \alpha$, Prot. Jas. 12.2), forgetting Gabriel's message ( $\dot{\varepsilon} \pi \varepsilon \lambda \dot{\alpha} \theta \varepsilon \tau 0$, Prot. Jas. 12.2), being afraid when her womb keeps swelling $(\varphi \circ \beta \eta \theta \varepsilon i \sigma \alpha$, Prot. Jas. 12.3), weeping ( $\varepsilon^{\prime \prime} \chi \lambda \alpha v \sigma \varepsilon(\nu)$, Prot. Jas. 13.3, 15.3) when defending her virginity, both mourning and laughing (see $\sigma \tau u \gamma v o ́ \varsigma / \sigma \tau u \gamma v \alpha \dot{\alpha} \omega \omega, \gamma \varepsilon \lambda \dot{\alpha} \omega$ in Prot. Jas. 17.2) on the way to Bethlehem, and finally being afraid $(\varphi \circ \beta \eta \theta \varepsilon i \sigma \alpha$, Prot. Jas. 22.2) that Herod's troops may harm the child.

These descriptions do add some depth to Mary's character but it is interesting that her emotions become mainly observable either in the context of divine revelation or when she defends her virginity. Ordinary or even stressful human encounters do not evoke any emotional reactions in Mary. The narrator is silent about Mary's emotions when she is given into Joseph's custody. We do not learn anything about her emotions when she is about to face the bitter water test, or about her relief after the positive outcome: only Joseph rejoices. Likewise, Salome's rude examination does not result in any emotional response on Mary's part. Mary's emotions are also hidden in the context of the actual delivery. That she does not feel any pain is in line with the author's theological ideal but it is notable that even any expression of joy is lacking in stark contrast to Joachim's and Anna's reactions when Mary was born (Prot. Jas. 4-7).

Mary expresses emotions in response to human action only in two cases. She becomes afraid of people seeing her womb swelling. Notably, this reaction, too, is related to her virginity being challenged, like when she is interrogated by Joseph and the high priest. The second time is in the last scene in which Mary appears in the Protevangelium of James, when she is afraid of Herod's troops and hides Jesus in a manger. Even in this case she is not mainly concerned for her own safety but for the child's.

Mary's character in the narrative is not totally flat. There is "a curve towards roundness," to use Forster's phrase (see above) but this curve seems to be instigated almost exclusively in the contexts where the role prepared for Mary

and non-believers. Thus, B. Dehandschutter, "Anti-Judaism in the Apocrypha," in Papers Presented to the Tenth International Conference on Patristic Studies Held in Oxford 1987: Historica, Theologica, Gnostica, Biblica et Apocrypha, ed. Elisabeth A. Livingstone. StPatr XIX (Leuven: Peeters, 1989), 346. 
in the divine plan is challenged in a way that also finds a resemblance in the author's contemporary context. To put it simply, when Mary speaks out, she speaks out for the author's case. On the other hand, she can also remain silent and submissive if that best serves the author's goals.

The narrative seems to be objectifying Mary for two reasons. First, the emphasis placed on Mary's purity and virginity is indicative of a development that is setting up the Virgin Mary as an object of veneration on its own. Second, the author of the Protevangelium of James contributes to this development by manipulating the traits of Mary's character that are related to emotional expression and human interaction in order to promote his own theological goals. The result is that in the Protevangelium Mary's character mostly lacks the kind of humane emotional and cognitive traits that would make it easy for devotees to identify with her. In this regard some other female characters are different.

\section{Anna}

The above discussion about Mary's character has already suggested that Anna's character is more round, especially in the contexts that involve human interaction. When Joachim banishes himself, because of his shameful childlessness, into the wilderness to pray and fast, we learn that Anna is lamenting and mourning (Prot. Jas. 2.1) ${ }^{37}$ for two reasons: because of her widowhood ${ }^{38}$ and because of her childlessness. The following scene, where Anna converses with her slave Juthine (Prot. Jas. 2.2-4), ${ }^{39}$ is also loaded with emotional tension. Anna replies angrily to her slave, who has urged her to stop mourning because the great day of the Lord ${ }^{40}$ is approaching. Juthine's reply is no less unsympa-

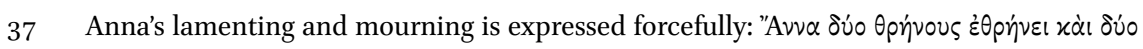

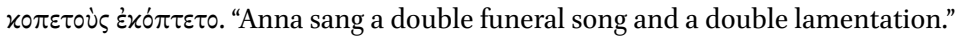

38 At this point the narrative does not clarify whether Anna actually believes she has lost her husband (thus, Vuong, Gender and Purity, 73-74) or simply feels like a widow because her husband has abandoned her in his great grief. The logic of the subsequent scenes supports the latter option, since Anna still prays for becoming pregnant, which would not make sense if she believed her husband had passed away. In Vuong's view (above) Anna's widowhood offers the author an opportunity to emphasize Anna's righteousness: she acts the way widows are supposed to act.

39 The name of the slave varies in the manuscripts and in the critical editions. De Strycker,

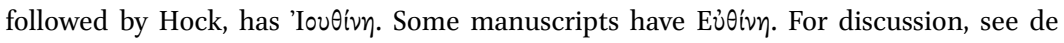
Strycker, La forme, 313-315.

40 The narrative does not explicate what "the great day of the Lord" is. The author, who views Judaism from an outsider's perspective, probably had in mind the combination of Yom Kippur and the Feast of Tabernacles, two great festivals that were close chronologically 
thetic: there is no need for her to curse Anna because God has already made her barren. This makes Anna sad. Anna's discussion with Juthine is followed by the most notable expressions of Anna's feelings in the Protevangelium, her long song of lamentation (Prot.Jas. 3), which has its counterpart in her thanksgiving after the birth of Mary (Prot. Jas. 6.3).

Anna's relationship with Joachim also includes more interaction and expressions of feelings than Mary's relationship with Joseph. When Joachim returns from his self-imposed exile in the wilderness, Anna rushes out and throws her arms around his neck declaring: "Now I know that the Lord God has blessed me greatly. This widow is no longer a widow, and I, once childless, am now preg-

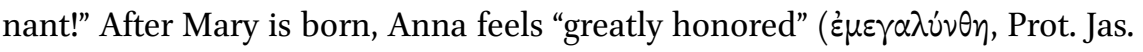
5.2). She also shows herself to be more sensitive towards the child's possible emotions (of which the narrative is silent!) when she suggests that she should not be taken to the temple at the age of two but a year later. This way she would not miss her father and mother so much (Prot. Jas. 7:1). When Mary is left in the temple Anna "marvels," "praises," and "glorifies" God (Prot. Jas. 8:1) together with Joachim.

In contrast to Mary, Anna's character actively contributes to the plot of the narrative. It is Anna who originally promises to give the child as a gift to the Lord (Prot. Jas. 4.1; in 7.1 Joachim agrees with this) while Joachim expresses his gratitude by offering generous sacrifices (Prot. Jas. 4.3-4). It is Anna who swears that the child is to be kept pure by not letting her touch the ground after her first seven steps. It is Anna who turns Mary's bedroom into a sanctuary and calls in the undefiled daughters of the Hebrews to amuse her (Prot. Jas. 6.1). She even dares to question Joachim's exhortation to take Mary to the temple at the age of two, and Joachim agrees with her (Prot. Jas. 7.1).

In part, the traits of Anna's character correspond to what was generally expected of women in antiquity. She is emotional and impulsive (running to Joachim and hugging him). She is also occupied with the domestic arrangements related to Mary's upbringing, while Joachim is responsible for the public sphere of life by socializing with the priests and other members of the Israelite elite. ${ }^{41}$ This pattern of behavior is obviously related to the aim of the Prote-

and which outside observers seem to have taken as one festival. See Daniel Stökl Ben Ezra, The Impact of Yom Kippur on Early Christianity, wUNT 163 (Tübingen: Mohr Siebeck, 2003), 68-69, 250, 254. Juthine's exhortation not to worry would suit the joyous character of the Feast of Tabernacles well. For discussion, see also Luomanen, "Judaism and Anti-Judaism," 324-325.

41 Carolyn Osiek and David L. Balch, Families in the New Testament World: Households and House Churches. The Family, Religion and Culture (Louisville: Westminster John Knox, 
vangelium to picture Joachim and Anna as a pious couple, prefigured in the stories of Abraham and Sarah as well as of Hannah and Elkannah. They also fulfill the general cultural expectations by leading reputable family life. Nevertheless, I find it remarkable that all the important decisions about Mary's future are made on Anna's initiative. In particular, it should (also) have been the father's task to decide about the future of his children, and when Anna questions Joachim's initiative to take Mary to the temple at the age of two, ${ }^{42}$ she makes herself equal to Joachim in this regard. ${ }^{43}$ When events are pushed in motion Joachim does fulfill his responsibilities in the public sphere, but Anna is the character who steers the plot. Therefore, if there is character that provides an example for active women, it is Anna, not Mary.

\section{Juthine}

Despite her brief appearance, Juthine's character shows interesting features and contrasts, all the signs of a round character (Prot. Jas. 2.2-3). Juthine has two lines in her conversation with Anna. Before the first line the narrator introduces her briefly as Anna's slave. All other information about Juthine's character is to be inferred from the content of her speech.

On the one hand, Juthine acknowledges her status as a slave by saying that in her position it would not be acceptable for her to use a headband with royal insignia. On the other hand, she dares to reprimand Anna for mourning when the great day of the Lord is approaching. Although Anna first replies in anger, later on she seems to agree with her since she takes off her mourning clothes and puts on her wedding dress. Anna's reply suggests that Juthine is socializing with disreputable persons: a trickster may have given the headband to Juthine. This suggestion presents a double challenge to Juthine's integrity. First, Anna

1997), 54-56; Ekkehard W. Stegemann and Wolfgang Stegemann, The Jesus Movement: A Social History of Its First Century (Minneapolis: Fortress, 1999), 364-377; Carolyn Osiek and Jennifer Poya, "Constructions of Gender in the Roman Imperial World," in Understanding the Social World of the New Testament, ed. Dietmar Neufeld and Richard DeMaris (London: Routledge, 2010), 44-56, esp. 45-48. Joachim is clearly presented as a wealthy man, which is often interpreted as one sign of the author's apologetic interests.

42 For the importance of the age three, see above n. 29.

43 The way decisions about Mary's future are made in the Protevangelium would better suit a Hellenistic than a Roman cultural context where the paterfamilias has more power over his children. See for instance, James S. Jeffers, The Greco-Roman World of the New Testament Era: Exploring the Background of Early Christianity (Downers Grove: Inter Varsity Press, 1999), 238-240. Nevertheless, even if we were to assume a Hellenistic cultural context for the Protevangelium, it is still remarkable that Anna takes the initiative throughout the part where Joachim and Anna appear in the narrative. 
does not trust Juthine's own account of where she received the headband, from a mistress of a workshop. Second, Anna hints that there is something sinful in the way Juthine has received the headband; one can infer that perhaps it is stolen or Juthine has received it from a disreputable lover. By receiving the headband Anna would become associated with Juthine's sin.

The way Anna addresses her slave is not surprising as such. That slaves were associating with suspicious persons and could well be involved with thefts belonged to stock traits of slave characterization in antiquity. ${ }^{44}$ However, Juthine's reply is unexpected. She strikes back right at the sorest point in Anna's character, her childlessness. There is no need for Juthine to try to curse Anna. She could not possibly do that more severely than God, who had already made her womb barren. In the end, Anna is disparaged even by her own slave.

Anna's and Juthine's dialogue is one of the most entertaining parts of the narrative. But why is it there? How does it serve the plot? It is generally acknowledged that Juthine is playing the same part as Peninnah, Elkannah's wife, who had children and who used to provoke Hannah because of her childlessness (1Samuel 1). In 1Samuel, Peninnah drives Hannah to despair and prayer. This also happens in the Protevangelium: Juthine's words make Anna sad and lead to her lamentation in the Protevangelium 3. On the other hand, the discourse also highlights Anna's steadfastness and piety: Although it should be time for the great festival and joy, Anna does not accept empty, outward decorations from a suspicious source. It is God who has shamed her. Therefore, she prays to God and accepts only the relief that comes from the Lord. ${ }^{45}$

\section{Elizabeth}

The scene that introduces Elizabeth's character exemplifies the same traits that are also observable in Anna's character: When Elizabeth hears Mary knocking at the door she "tossed aside the scarlet thread, ran to the door, and opened it for her." Her impulsive reaction conforms to what was expected of female characters. ${ }^{46}$ The scarlet thread, the spinning of which is also Mary's task, signals that Elizabeth, too, was among the true virgins "from the tribe of David" selected for the weaving of the temple veil (Prot. Jas. 10.1; 12.1). These traits were

\footnotetext{
44 Cf. Jennifer A. Glancy, Slavery in Early Christianity (Oxford: Oxford University Press, 2002), 133-134.

45 In this regard, I agree with Vuong (Gender and Purity, 74-75), but I do not think that Juthine offers "continued misinterpretations" of Anna's situation. Juthine's character is more complex. She partly functions as a foil (as Vuong suggests) but she also offers correct advice when she reminds Anna about the upcoming joyous festival.

46 Osiek and Poya, "Constructions of Gender," 46.
} 
obviously quite important for the author to communicate because they are in contradiction with the fact that Elizabeth was already married.

Elizabeth also shows traits of a typical female character in the next scene where she appears. When Elizabeth hears that Herod was looking for her son John, she also, like Mary, starts to look for a place to hide him (Prot. Jas. 22.3). She goes up to the hill country where she "groans" ( $\sigma \tau \varepsilon v \alpha \dot{\alpha} \xi \alpha \sigma \alpha \ldots \varphi \omega v \hat{\eta} \mu \varepsilon \gamma \alpha \dot{\alpha} \lambda \eta)$. The narrator's explanation for this groaning is telling: Elizabeth was unable to climb because of fright ( $\delta i \dot{\alpha} \tau \dot{\eta} \nu \delta \varepsilon i \lambda \hat{i} \alpha \nu) .{ }^{47}$ However, the mountain splits hiding Elizabeth and John.

The author considered it unnecessary to provide any introductory information about Elizabeth. He must have assumed that the audience knew who Elizabeth was. The author uses Luke's discourse word for word at several points, but he is not at pains to harmonize his own discourse with Luke. The points where his characterization differs from that of Luke seem to be either theologically motivated or based on typical female stock traits.

\section{The Midwives and the Undefiled Daughters of the Hebrews}

The first midwife in the narrative is Anna's midwife. Her character is a typical walk on, she appears only once in the story and does only what a midwife is expected to do. The narrator does not name her or disclose anything about her personal traits. First-time readers or hearers of the discourse hardly remember her part. Such is not the case with the midwives in the context of Mary's delivery.

After having placed Mary safely in the cave Joseph goes out to look for a "Hebrew midwife." When he meets a woman coming down from the hill country, their exchange of words focuses on ascertaining that they both are Hebrews/Israelites (Prot. Jas. 19.1). The first midwife's testimony links up with Israel: "I have really been privileged, because today my eyes have seen a miracle in that salvation has come to Israel" (Prot. Jas. 19.2). The second midwife, Salome, wants to examine Mary. Although Mary is submissive, Salome receives her punishment when her hand is consumed by flames. When Salome starts praying her Israelite background also becomes clear. She refers to her Israelite ancestors Abraham, Isaac and Jacob, and reminds the Lord that she has been healing people in his name. The "Lord of all" hears her prayer and instructs her to pick up the child in order to be saved. Salome does as told, saying: "I'll worship him because he's been born to be king of Israel." She is healed. ${ }^{48}$

Hock (The Infancy Gospels, 73) translates "because her nerve failed her." For courage

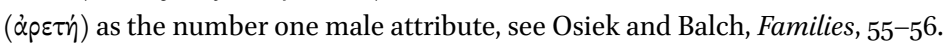

48 Cf. Catherine Trautmann, “Salomé l'incrédule: Récits d'une conversion," in Écritures et 
The two midwives function as each other's foils, exemplifying the twofold reception Mary predicted when she was riding Joseph's donkey. Besides being examples of belief and unbelief the most important trait that the midwives share is their Hebrew ancestry. Both are also eventually vindicated.

If the Protevangelium was written in response to Jewish attacks on Mary's character and background, it was naturally important for the author to point out that the midwives who testified to - and tested-Mary's virginal delivery of the child were Hebrews themselves. The "undefiled daughters of the Hebrews" who entertained Mary in her home sanctuary and escorted her to the temple at the age of three serve the same purpose: Mary's purity was secured by the reliable daughters of the Hebrews. Although the scenes where the midwives appear are quite colorful, the characterization of their personalities remains relatively flat, serving mainly the theological goals of the author. Even more so is in the case of the undefiled daughters of the Hebrews. They function as collective walks-ons whose characterization is exhausted in the way they are termed: they are undefiled daughters of the Hebrews and as such they fulfill their background role in the narrative by giving credence to the author's claim about Mary's purity.

\section{Conclusion}

Narrative analyses of the Protevangelium of James have paid much attention to Mary and her characterization. Although Mary has been pictured as the protagonist of the narrative, her character has appeared as relatively passive and flat. On the one hand this has been taken as a standard feature of biblical characterization that uses flat characters but creates depth through contrasts and comparisons in the plot. Furthermore, the cases where Mary is active and speaks out are assigned special significance as instances where Mary's character provides a role model for active women who defend their integrity in front of the highest male authorities.

My analysis of Mary's character concurs with the earlier analyses by acknowledging the central role of purity in the narrative and the character's relatively flat and submissive traits. However, when other female characters in the Protevangelium are taken into account it becomes clear that there are

traditions dans la littérature copte, ed. Jaques É. Ménard. Cahiers de la bibliothèque copte 1 (Louvain: Peeters, 1983), 62, 68. As pointed out by Trautmann, Salome also appears as a witness of Jesus' divine origin in the Gospel of Thomas, logion 61. 
also more round and deeper female characterizations. Mary's characterization therefore cannot be taken simply as one instance of characterization that is typical of biblical characterization in general.

Especially the characters of Anna and Elizabeth include more emotional expressions and other traits that were considered to be typical of female behavior. Anna, in particular, engages in emotional interaction and dialogue both with her slave Juthine and her husband Joachim. Anna's initiatives and actions are also crucial for the plot development. If there is a role model for active women in the Protevangelium, it is Anna, not Mary. Since Anna is Mary's mother, the contrast in the traits of their characters is all the more striking.

The undefiled daughters of the Hebrews and the Hebrew midwives are also relatively flat characters. In that regard they resemble Mary's character. Their main function in the narrative is to give credence to the author's central claims about Mary's purity and virginity.

Instead of taking the flat and submissive traits of Mary's character as the author's technique to highlight the points where Mary takes a more active role, I suggest that the sterile and passive outlook of Mary is indicative of a development where Mary is being made an object of veneration and simultaneously defended against Jewish accusations. The Protevangelium of James contributes to this process by emphasizing Mary's extraordinary purity. Mary does not engage in ordinary human interaction and dialogue that would cause emotional arousal. Her emotional and cognitive state of mind is referred to almost exclusively at the points where she encounters divine messengers or defends her virginity.

Mary's character is subjugated to the promotion of the male author's theological agenda. In the process, Mary also becomes less feminine - or more masculine, depending on one's point of view. The masculinization of Mary's character brings to mind logion 114 in the Gospel of Thomas where becoming male is a prerequisite for female disciples to be saved. Logion 114 requires Mary Magdalene to become a male, living spirit like Jesus's male disciples, since "every woman who makes herself male will enter the kingdom of heaven." Although the overall ideologies are quite different, it is possible that the same cultural and philosophical convictions that are behind the Gospel of Thomas's views about women's way to salvation are also operative in the Protevangelium. ${ }^{49}$

49 The connection seems likely especially if one adopts Marvin Meyer's interpretation of logion 114 which emphasizes the cultural values attached to masculinity and femininity in antiquity. See Marvin Meyer, "Making Mary Male: The Categories 'Male' and 'Female' in the Gospel of Thomas," NTS 31 (1985): 554-570, esp. 561-567. For a balanced assessment 
When the high ideals of purity are attached to Mary's character her personality also becomes stripped of other weak female traits. In the Protevangelium of James Mary is not to become fully male — but she is made clearly less female.

of different ways to interpret logion 114, see Antti Marjanen, The Woman Jesus Loved: Mary Magdalene in the Nag Hammadi Library and Related Documents. Nag Hammadi and Manichean Studies 4o (Leiden: Brill, 1996), 43-52. See also Ivan Miroshnikov's essay in this volume. 